\title{
The Process and Forms of Labelling Learners in Zimbabwean Schools: A Challenge
}

\author{
Manuel Rwodzi \\ University of Zimbabwe, department of Educational Psychology, Zimbabwe
}

\begin{abstract}
Norma $\mathrm{Nel}^{*}$
University of South Africa, College of Education Department of Psychology of Education, South Africa
\end{abstract}

\section{Soezin Krog}

University of South Africa, College of Education, Department of Early Childhood Education and Development, South Africa

\begin{tabular}{ll}
\hline \hline Article history & $\begin{array}{l}\text { This article gives a bird's eye view of a doctoral thesis which investigated } \\
\text { Received: }\end{array}$ \\
the labelling of non-disabled secondary school learners, with particular \\
reference to the social and psychological spheres, and their influence on \\
Received in revised form: & $\begin{array}{l}\text { learning. It reports on the process and forms of labelling as one part of the } \\
\text { findings. The study had 54 participants: three school headmasters, } 9 \text { form }\end{array}$ \\
& three teachers, 8 lower sixth form teachers, 18 form three learners and 16 \\
Accepted: & lower sixth form learners who were purposively sampled. A qualitative \\
16.05 .2018 & research approach was adopted, in which phenomenological interviewing \\
Key words: & was done with learners, their teachers and school headmasters; focus \\
\hline labelling; Zimbabwean; & group discussions were held with learners and document analysis was \\
process; forms; challenges & done on teachers' work schemes and records of work. It was found that \\
& the process of labelling was predominantly shaped by agents from the \\
& home (parents, guardians) and the school (learners' class and subjects, as \\
& allocated by teachers and school headmasters), rather than the learners \\
& themselves. Several forms of labelling emerged as further challenges \\
& relating to school type, and the screening and streaming of learners. The \\
study presents recommendations for addressing challenges emanating \\
from such labelling, which includes crafting a policy framework to that \\
effect.
\end{tabular}

\section{Introduction}

To label is to "designate", "stigmatise", "brand" and "ascribe a quality to or give a name of a common noun that reflects a quality" (The free dictionary, 2012). As the definition suggests, the labelling of learners involves a process whereby the deviant act (in this case labelling) is normalised (Lemert in Giddens 2001, 210) along with its many forms (performance-based labelling in order to stream/screen learners for designated subjects according to ability) impacts the lives of children. This study aims to address its negatives 
(both potential and actualised), and positives (if any). While the labelling of learners has been significantly studied, as evidenced by the work of, inter alia, Becker (1963) and Matza (cited in Haralambos, Holborn, Chapman and Moore 2013), Lu (2012), in Taiwan, Hallam and Parsons (2013) in the United Kingdom, Ferrare (2013) in the United States of America (US), and Matavire, Mukavhi and Sana (2012) in Zimbabwe, there is room for further investigation. Osterholm, Nash and Kristons (2007) declare labelling to be a controversy which is still unresolved in terms of both its benefits and its ill effects. Further, Unesco (2008), in its January policy briefs, states that categorising students based on attainment (a form of labelling) could increase inequalities and inequities, particularly if it takes place early on in the education process.

The Zimbabwe Education Act (Republic of Zimbabwe, 1996, 619) articulates that "[n]o child in Zimbabwe shall be refused admission to any school" due to his/her race or his/her parents' social status, and that school authorities should ensure the "fair and equitable provision" of education. However, despite such legislation, labelling is prevalent in Zimbabwean schools, as confirmed by researchers such as Riddel and Nyagura (1991), Chisaka and Vakalisa (2003) and Mufanechiya and Mufanechiya (2011). Further, labelling - in the form of streaming and screening according to ability in respect of subject choices such as arts, commercials and sciences (the focus of this study) - has been found to date back to the colonial era. Since then, labelling has become so institutionalised that, despite its negative effects, few schools in Zimbabwe do not stream according to ability (Matavire et al., 2012, 280).

Segregation of low ability learners in the curriculum result in learners feeling alienated (Machingambi 2012, 61). Antagonism results among teachers of different groups and subjects, that is teachers who teach high ability classes look down on teachers teaching low ability learners. This also applies to high ability learners looking down on low ability learners (Matavire et al., 2012, 282). Labelling of learners according to school type has also been rife in the Zimbabwe education system as it affected learners' achievement differently (Ridell and Nyagura, 1991).

We need to acknowledge however that there is an upside to streaming by ability such as revealed by Matavire et al., $(2012,282)$ that as learners work with their peers they benefit from each other. Mufanechiya and Mufanechiya $(2011,101)$ explains that learners have a big influence on each other therefore it is an important source of identity and motivation. Labelling could positively or negatively influence various aspects of learning, including class performance and learner motivation.

Considering the prevalence of labelling within the Zimbabwean education system, it is of paramount importance to continuously research the issue, in order to capture its current state. Thus, the present study represents an interrogation of the labelling of learners through streaming and screening according to ability when it comes to subject choices, and in doing so, focusing on its process and forms. A particular emphasis is on the psychological and social spheres and how they influence the learners' academic performances. The study involved form three and lower sixth learners. Form three is the third year of secondary school after seven years (or nine years, if one includes two years of early childhood development education) of primary school learning. Lower sixth form learners are in their fifth year of secondary school education. At the end of the sixth year (upper sixth form) of secondary school the learners sit for examinations equivalent to those of the General Certificate Advanced Level examinations run by the Cambridge Examinations Board, the "normal" qualification leading to university entrance. 
The knowledge subsequently generated will help education stakeholders comprehend the workings and impact of this phenomenon, while doing away with much of the concomitant negativity. To achieve this, labelling must be addressed by employing both preventive and problem-solving measures (through policy formulation as well as institutional and teaching management). The research findings aim to add to the body of knowledge pertaining to the labelling of learners not only in Africa, but also in the rest of the world. It is against this background that the research questions were formulated.

\section{Literature Review}

This section reviews literature that highlights issues related to the labelling of learners. The review contextualises the present research and relates it to studies done in Zimbabwe and elsewhere, so as to obtain a comprehensive understanding of, and provide a clear position on, current research into the phenomenon.

Evidence shows that in the wider world, various forms and processes of labelling are practised, which consequently influence and have repercussions for the products of any education system: the learners. Following a general overview of the situation in the US and Africa (being the continent on which Zimbabwe is situated), the review will focus on Zimbabwe.

Amidst a reported upsurge in ability grouping, some researchers have questioned the usefulness of the practice. Based on findings in the US, Segedin $(2012,93)$ argues that streaming diminishes learning. Further, the American education system was found to create a cycle in which learners who started out ahead were even further advantaged (Sanders 2013). In Africa, the continued labelling of learners has had contrasting outcomes in countries such as Nigeria, where Adodo and Agbayewa $(2011,48)$ found that homogenous ability grouping was superior for promoting learner achievement in their different ability levels. Similarly, in Kenya, Bosire, Mondoh and Barmao $(2008,95)$ revealed that, generally, streaming based on gender improved overall learner achievement in mathematics - amongst girls in particular and that learners were less stigmatised in a homogeneous ability-level class. However, these merits of labelling were contradicted by the demerits/negative findings arrived at in various African countries. In Ghana, Agbenyega (2012) found that labels more negatively than positively influenced how a teacher managed the instructional process. In Kenya, the findings of Bosire et al. (2008) contradicted those of Adodo and Agbayewa (2011), noting that learners taught in normal, mixed classes scored relatively higher than those in either mixed-segregated or single-sex schools.

In Zimbabwean schools, labelling has been prevalent in various forms (see, e.g., Riddel \& Nyagura 1991; Chisaka \& Vakalisa 2003; Mufanechiya \& Mufanechiya 2011; Matavire et al. 2012). The demerits of streaming have been found to include disadvantaging especially lowability learners, while negatively labelling the teachers who teach them. Labelling by school type was already rife in Zimbabwe's education system more than two decades ago (Riddell \& Nyagura 1991). Further, Mufanechiya and Mufanechiya $(2011,101)$ note that the labelling of learners has led to the 'segregation' of low-ability learners within the curriculum. In addition, Chisaka and Vakalisa (2003) conclude that ability grouping does not improve teaching or instruction and learning, but instead encourages unhealthy social stratification where learners in high-ability classes and those in low-ability classes feel they have nothing in common, even outside of their segregated classrooms. By contrast, numerous Zimbabwean researchers, such as Chisaka and Vakalisa (2003), Mufanechiya and Mufanechiya (2011) and Matavire et 
al. (2012) have indicated that labelling benefits learners in high-ability classes.

The review of the literature presents the labelling of learners as a contradictory practice. It is thus essential that the current position on this practise, as it manifests in various forms and processes in Zimbabwe, be documented. This is especially so since labelling has the potential to influence learning, most likely negatively, particularly for low achievers. In addition, as Reyes $(2010,12)$ argues, in an education system which allows labelling to take place, the rights of individuals to pursue equal educational opportunities, as advocated by the International Human Rights Charter, become impossible, further justifying the need for the present research.

\section{Reflections on the labelling of learners through theory}

We acknowledge various theoretical perspectives which can shed light on the issues related to labelling, by promoting a comprehensive understanding of, and insight into, the phenomenon. Theories such as the social constructionist perspective; the conflict theory perspective; structuralism; functionalism; the psychodynamic perspective; the behaviourist perspective; Gestalt psychology; the humanistic perspective; the cognitive perspective; the social learning perspective; Vygotsky's sociocultural theory; ecological systems theory (Bronfenbrenner); the biological perspective; naming; theories of disability and the pedagogy of the oppressed (Freire) were discussed in terms of their relevancy to labelling. For the purpose of this article, the authors have chosen Bronfenbrenner's Ecological Systems theory to underpin the study.

According to Bronfenbrenner's bio-ecological theory, five levels of environment influence the learner's development namely: the microsystem which includes the home and school, within the mesosystem which represents the linkages between the home and the school, which is embedded within the exosystem (the parents' work environment) and which are in turn all influenced by the chronosystem (time period) (Woolfolk 2014, 86). Patterson (2008) describes the microsystem as including the learner's home and school where there are faceto-face interactions with their parents, brothers and sisters, teachers and peers which characterise their experiences. In the mesosystem there are connections in the various microsystems such as the life of learners at home and at school. Their experiences at home influence how they deal with situations during school. The exosystem (e.g. parents' work environments and community groups) where the learners do not inhabit but nevertheless which affects what they experience. The macrosystem consists of social class, ethnic and cultural customs and government laws which frame the learners' and their families' activities. All these aspects of the child's environment undergo change over a period of time which may take place as they grow, which is the chronosystem.

In Bronfenbrenner's later work he looks at the bioecological processes (developmental processes) which involve biological organisms (our living bodies) and ecological conditions (the environments in which we live) (Patterson 2008). Bronfenbrenner shifts the emphasis from the environments to identification of processes whereby bioecological interactions in environments take place, which in this case is the labelling of learners. Based on the fact that development is considered as a function of biological processes in the organism as well as the ecological processes in the environment it explains the process of development (Patterson 2008). The argument would be that since the learners are biologically different and they are socialised differently regarding issues of life they are not similar, which justifies dissimilar treatment regarding being taught and consequently necessitate the need for different 
classifications (labelling). Bronfenbrenner poffers that various social and cultural environments influence the child individually as well as their interactions. Their home and schools are located within neighbourhoods which in turn are located in cultural groups that prescribe their customs and their values (Patterson 2008:25). The authors believe that by labelling learners in Zimbabwean secondary schools, the educators as well as the policymakers could be creating psychological and social challenges which affect the learners.

Osterholm, Nash, and Kristons (2007) assert that because labelling is not static there is a need for continuous investigation which has propelled this research.

\section{Method}

\section{Research methodology}

The main research question for the thesis was: What are the social and psychological ramifications of labelling Zimbabwean secondary school learners and their influence on the learners' academic performance? The qualitative approach was used and the phenomenological (interpretivist) research approach/design, mainly guided the study. In this article, the authors report on two sub-research questions: (a) How does the process of labelling secondary school learners (form three and lower sixth form) with specific reference to screening, streaming, ability grouping and subject allocation, manifest itself within the present context? and (b) What are the forms and nature of labelling of learners operating within the Zimbabwe secondary school system?

\section{Population and sampling}

The study population consisted of two districts in and around the city of Harare in Zimbabwe, where 20 secondary schools are located. On average, each school had at least 500 learners and 30 teachers at that time, and this is where the sample was derived from.

Purposive sampling was employed to arrive at 54 participants (three school heads, nine form three teachers, eight lower sixth teachers, 18 form three learners and 16 lower sixth learners). This sampling describes the process of selecting research participants on the basis of their relevance to the research (Gibson \& Brown 2009, 56). The purposive sampling was complemented by stratified sampling, which focuses on samples within samples. This provided for sampling according to the various variables within the research: school type (former group A government/secondary school 1/S1, former group B government/secondary school 2/S2 and private secondary school), form (third and lower sixth), subjects of specialisation (arts, commercials and sciences) and gender.

Former group A government secondary schools welcomed white children during the colonial period, prior to independence. Currently, the school is attended by children from relatively wealthy families who can afford the high fees charged to maintain the status or class of the school. Former group B government secondary schools welcomed black children during the colonial period. Currently, the learner profile comprises a majority of black children who are generally poor, and the fees charged are relatively low. These erstwhile classifications are popularly known in the Zimbabwean context, and seem to perpetuate the labels attributed to schools. Private schools were (and still are) owned by individuals, partners or groups, without government or state involvement. The school fees and levies which private schools charge are usually higher than those charged by $\mathrm{S} 1$ and $\mathrm{S} 2$ schools, and as a result these facilities tend to be better resourced. 
The teachers were selected according to the labelling of the learners they taught, for example, in terms of ability or streaming at form three and subjects learnt at lower sixth level (arts, commercials and sciences). The learners were selected equitably under the classification of the teachers, for instance two arts, two commercials and two sciences learners, with gender balance wherever possible.

\section{Instruments}

The instruments used for collecting data in this research were individual (phenomenological) interviews (learners, teachers and school heads), focus-group interviews and document analysis schedules. This was done for the purpose of triangulation (of instruments), which made the research more trustworthy as each brought a particular kind of insight to the study (Ritchie 2008).

The research included two focus-group interviews with learners from each school type - one from form three and the other from lower sixth form. The multiple voices not only fleshed out the findings, but also complemented the data derived from the individual interviews.

All the sampled school heads, teachers and learners were interviewed according to the respective interview schedules. Interviews were conducted with those who had experienced labelling, until the point of saturation was reached. To support the interviews, teachers' teaching documents (schemes and records of work) were analysed.

\section{Analysis of data}

The interviews were recorded and manually transcribed. The data were coded using symbolic characters and colours. Themes, their categories and other issues which emanated from the participants' responses were identified and a report was compiled. Data from indepth interviews with individual learners formed the core of the report, with data from the focus-group discussions with learners, individual interviews with teachers and representatives of school heads (deputy heads/senior masters), as well as from the analysis of teaching documents being used to complement, supplement and reflect on the findings. The documents under study included teachers' schemes of work and progress record books. These helped determine how and what the differently labelled learners were taught, what the teachers had prepared, and what and how they taught their learners. The major themes and their categories which emerged from the data are captured in Table 1 below.

Table 1: Themes and categories

\begin{tabular}{|c|c|c|}
\hline Themes & & Categories \\
\hline 1. & $\begin{array}{l}\text { The process of labelling secondary school } \\
\text { learners in Zimbabwe }\end{array}$ & $\begin{array}{l}\text { - The home as an agent of the labelling } \\
\text { process } \\
\text { - Learners as agents of the labelling process } \\
\text { - The school as an agent in the process of } \\
\text { labelling learners: The learners' class as } \\
\text { an agent in the process of labelling } \\
\text { learners } \\
\text { Learners' subjects as an agent of the } \\
\text { process of labelling }\end{array}$ \\
\hline 2. & $\begin{array}{l}\text { The forms of labelling secondary school } \\
\text { learners in Zimbabwe }\end{array}$ & $\begin{array}{l}\text { - } \quad \text { School type as a form of labelling learners } \\
\text { - } \\
\text { - }\end{array}$ \\
\hline
\end{tabular}


First we offer an illustration that depicts how the emerging themes influenced the learners.

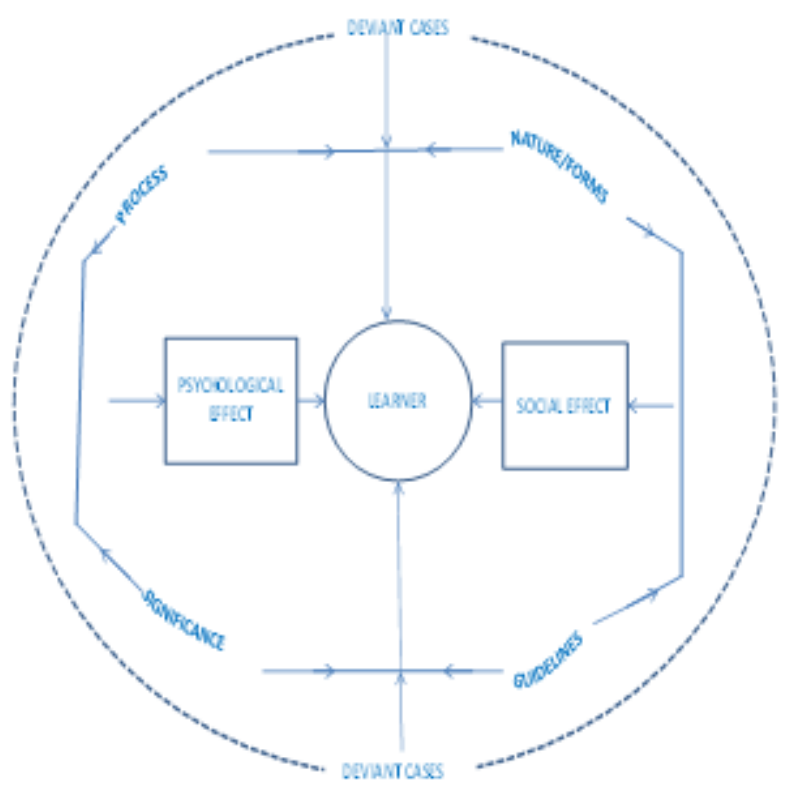

Figure 1: Labelling Themes' influence on learners in the Zimbabwean Education System.

We concentrated on the challenges which led to the analysis of guidelines on addressing the problem of labelling learners. Learners offer possible solutions to the challenges during focus group interviews. The peak focus namely psychological and social challenges emanated from the labelling of learners not disregarding other emanating themes.

In the following sections we deal with the themes by presenting the data collected from the data collection tools, which we analysed and discuss within the context of the literature review. Finally, the eventual conclusions drawn which emerged from the analysis of the data are presented.

\section{Discussion of Findings}

The findings are discussed under the two main themes and their accompanying categories, which emerged from the transcriptions of the recorded interviews.

\section{Theme 1: The process of labelling secondary school learners in Zimbabwe}

The process of labelling Zimbabwean secondary school learners was constituted by various sub-processes, many of which were quite similar in the three schools under study. These sub-processes were mainly executed by agents of the home and school.

\section{The home as an agent of the labelling process}

The home, according to Bronfenbrenner (1994), is a key constituent of the microsystem, which has a significant influence on the child (Patterson 2008). In-depth and focus-group interviews with learners revealed that their parents/guardians acted as agents from home who influenced the process of labelling learners quite significantly, especially at government former group A and B schools. For example, during the individual in-depth interviews, a male school A form three arts learner stated: My parents forced me to come and learn at this school. 
Thus, parents put the process of labelling learners into motion by deciding where their children will learn. This was confirmed by most learners during focus-group discussions involving form three participants. This action on the part of the parents presented a challenge, in that it was compulsory and left the learners with no choice at all. However, at private school $\mathrm{C}$, the majority of form three participants indicated that they had not been forced by their parents to enrol at that school, but that they had chosen to be there. These revelations indicated a trend which the lower sixth participants confirmed. Learners from school $\mathrm{C}$ were actually proud of not being forced to attend their school. However, many learners - especially from schools A and B - suffered the consequences for the decisions of their parents: for instance, a male school B lower sixth arts learner stated I didn't want to learn here because there are better schools than this one, only my parents compelled me to learn here. This statement indicates a clear dislike of the school. Thus, the initial process of labelling presented a challenge in that it was executed by agents other than the learners themselves (usually parents/carers).

\section{Learners as agents of the labelling process}

Through the influence of their homes, a small number of learners had a significant impact on the process of their own labelling (as a preferential status), in that they were allowed to choose the schools they wished to attend, at both form three and lower sixth form levels. This situation was more prevalent at private school $\mathrm{C}$ than at government schools $\mathrm{A}$ and B, especially at form three level. According to the humanistic perspective, exercising freedom of choice provides an individual, positive motivation; it allows for self-actualisation (Woolfolk 2014, 479) in the learning process (i.e., becoming the best that you can be). By contrast, at government schools A and B, unlike at private school C, the majority of lower sixth form learners indicated that the home system had merely placed them in their schools (in agreement with the school system), regardless of their wishes as learners. On the other hand, as for the school $\mathrm{C}$ learners, the few who were allowed to choose where they would be schooled had the same positive effect in that they felt confident in themselves and comfortable with their learning. During the individual in-depth interview Learner 17, a female School B Form 3 commercials learner stated that My mother gave me several school options and I chose my present school because it had facilities like a library, and it is better than my former school.

Thus, as revealed by many learner participants from schools A and B, in many Zimbabwean homes the challenge they faced was not being allowed to take responsibility for their own choice as to where they would be schooled. The initial process of labelling learners in collusion with forces exerted by the home (Ecological Systems Theory [Bronfenbrenner 1994]) mainly coerced them into a particular school; consequently the school itself (another force within the microsystem) took over in shaping the process of labelling learners.

\section{The school as an agent in the process of labelling learners}

The school is responsible for labelling learners in terms of the type of school the child attends, the class s/he is allocated to, and the subjects s/he takes. The type of school learners attend was revealed to be an agent of labelling at both form three and lower sixth form levels, and at all three types of school. When compared to the learners at private school $\mathrm{C}$, most learners at government schools A and B showed a dislike of their type of school. For example, a female school A form three sciences learner said her parents had enrolled her there against her will. She would have wanted to attend a different school, because of the poor quality of education offered at her present school, compared to other schools. Similarly, a male school B 
form three arts learner indicated that he disliked his school because most teachers did not attend lessons and learners were not really focused on their schoolwork. However, most learners at private school $\mathrm{C}$ liked their school. In this respect, a female school $\mathrm{C}$ form three commercials learner was quite positive as she opined that I think it's the best school type in our area, so I decided to come here than anywhere else.

Clearly, the type of school contributed to the process of labelling learners, with private school $\mathrm{C}$ being more positively perceived than the former group A and B government school types. However, at lower sixth form level, school B was viewed more positively by learners than school A. As confirmed by many of the participants, a male school B lower sixth form arts learner stated Ifeel honoured to be here, a great school, good learning environment.

No such praiseworthy remarks were forthcoming from school A lower sixth form learners about their school. Thus, the mere fact that learners attended different schools (former government schools $\mathrm{A}$ and $\mathrm{B}$, and private school $\mathrm{C}$, with which learners identified strongly), was a way of labelling them. As revealed above, each type of school has its own characteristics which, by implication, influence learners in a unique way. Therefore, given their diverse environments, the schools were geared for differences in terms of the actual learning taking place, which may point to greater challenges being encountered at government schools A and B than at the private school C. The implication is that selected government schools have a better status than others and private schools are still regarded as having a better status.

Just as they were never consulted on their choice of school, the interests of the form three learners at government schools A and B did not greatly affect which class they were placed in, or, by implication, the process of their labelling. A female school A form three commercials learner, for instance, stated We were put into classes: arts, commercials and sciences, based on our form two third-term examinations results and never consulted about what class one wanted to be in. Thus, the schools were doing a disservice to the learners, as shown by a female form three arts learner at school B, who revealed that she had cried upon being placed in the arts class, where she did not want to be. Such labelling stressed the learners and denied them freedom and self-determination, as advocated by humanists (Woolfolk 2014, 479). A learner's self-determination, like his/her attitude, positively influences performance (Mahmud 2009). Consequently, by implication, a lack of ownership of the process of their labelling was bound to produce negative results in terms of learners' performance.

The form three learners at school $\mathrm{C}$ were more in control of the process of their labelling. This made them proud of themselves, as reflected in many of their responses. For instance, at school C a male form three sciences learner stated I feel good, because I am doing something I have always wished and chose to do. Such an undertaking brings about the right attitude towards learning and, according to Rwodzi (2006), and is bound to bring about improved learner performance.

Ironically, though, the lower sixth form learners at schools A and B thought that they were really in charge of the process of their labelling, by working hard to be in a particular class. However, that connoted a challenge in that the learners were going so far as to tailor-make their lives to fit into a straight-jacket (class) - a label which had already been decided for them by school personnel (school heads, teachers, examination makers, and so on). This was determined by their overall passes: top learners for the sciences, followed by commercials and 
lastly the arts. However, at school C, while the learners' passes were quite influential, their interests and choices also took centre stage and they were proud of that. For example, a male school $\mathrm{C}$ lower sixth arts learner expressed that It feels good to be able to determine one's fate through being able to choose the class of one's interest.

Thus, of the three school types, private school $\mathrm{C}$ presented less of a challenge by being the most permissive, enabling learners to take responsibility for the process of their own labelling, by allowing them to choose which class to belong to (from amongst the arts, commercials and sciences streams). Once the learners had been labelled according to class, the process of labelling them was shaped through the allocation of subjects.

\section{Learners' subjects as an agent of the process of labelling}

The allocation of subjects to form three learners at government schools A and B, was mainly the prerogative of the school administrators, as most participants revealed. For instance, a female school A form three arts learner explained that We were told what to learn!:

While subjects are presented as packages (sciences, commercials, arts), the learners clearly articulated that within each package, schools should offer many subjects to choose from, in a variety of combinations. Even at school $\mathrm{C}$, which normally allowed learners choices, there was evidence of learners being unhappy with their labelling, as they were not allowed to choose their subjects. A male school $\mathrm{C}$ form three arts learner, for instance, said he felt "mad about not being allowed to choose" because he wanted to take commercial subjects rather than arts subjects. Thus, the system of labelling learners may foster negative feelings. This was more so for arts learners, since a pattern emerged throughout the research that those learners were least served by the system, while learners who took science and commercial subjects were better served. Teacher 14, a male school C lower sixth commercials educator, said that : Many graduates are surviving on odd jobs like selling airtime because of the poor economy. When the current learners realise the reality of their situation, they may develop a negative attitude towards their learning/subjects.

The same pattern of subject allocation (on which learners had little [if any] influence) which was found at form three level, thrived at lower sixth form level of all three schools, but was less evident at private school C. Most school C lower sixth form learners were happy about being able to choose their subjects. As a female school C lower sixth arts learner asserted I feel considered as an adult by having my choice considered, I feel trusted. Further, a female school C lower sixth sciences learner confidently articulated I feel pretty good about taking the science subjects, because I am doing the subjects which I chose and which will allow me to train in the software engineering field, which I am interested in.

Like these private school $\mathrm{C}$ learners, most learners at government schools A and B were quite clear that they wanted to be personally responsible for the process of their own labelling, by being allowed to choose the type of school they attended, the class they were in and the subjects they took. The learners did not like other agents (from home or school) dominating the entire process, to the point where it became oppressive (Freire 2005). This approach to subject allocation presented challenges to the learners, as it made them mere recipients of/pawns in the process. The learners wanted to be accorded a chance to shape their own destinies by being responsible for the process of their labelling, through having their interests and choices recognised. 


\section{Theme 2: The forms of labelling secondary school learners in Zimbabwe}

As advocated by Teacher 12 a male school $\mathrm{C}$ lower sixth sciences teacher, the labelling of learners needs to overcome those pitfalls of formal education introduced by colonialists and says It's unfortunate the way this education was brought to us, it was meant as a tool to group us, a bottle neck system by the settlers. They just wanted those with "sharp" brains and would say the "weak" ones didn't have space; their place was for the unskilled jobs.

Most of the identified forms of labelling showed strong correlations rather than differences, and cut across all three school types.

\section{School type as a form of labelling learners}

The school types involved in the present research were former groups A and B government secondary schools and private school $\mathrm{C}$ (see the section on 'Population and sampling' in this article). The different types of schools implied an advance form of labelling, since the learners in each were bound to be exposed to experiences which were unique to that particular school. This was confirmed by many learner participants: for instance, a male school A form three commercial subjects learner stated I didn't want to learn at this type of school, where my parents forced me to be because there are better ones than this one. By contrast, many form three learners at school $\mathrm{C}$ stated that they felt well served by being at that private school.

At lower sixth form level, the findings pertaining to school type correlated with those at form three level, namely that the different types of schools affected the learners differently. For Riddell and Nyagura (1991), different school types affect students' achievements in different ways. In the present research, private school $\mathrm{C}$ was a more learner-friendly school type in terms of serving learners' interests: they could choose which classes to join and which subjects to take. An analysis of the teaching documents in the present research also put teachers at private schools ahead of those at government schools in terms of the planning (scheduling) being up to date, the scheduled work being covered and the quantity of marks recorded. These revelations meant that the schools were indeed different not only based on their labelling, and that learning at these diverse schools meant that particular labels were attached to the learners at each school.

\section{Screening as a form of labelling learners}

In the present research, screening was understood as the practice of selecting certain learners and barring others, based on specific criteria. Such screening took place in forms one, three and lower sixth, based on the quality of the learners' passes. Government schools demanded higher passes than the private school did. Thus, screening on first entry into the school, in addition to the school type, was another significant form of labelling to which Zimbabwean secondary school learners were subjected - more so at government schools than private schools. Many learners indicated that screening constituted a challenge, for instance, one female school A form three commercials learner stated that Screening would affect some learners and would destroy some learners' future since it's based on an examination, which if taken when one is not feeling well, may disadvantage such a learner.

The International Human Rights Charter advances the pursuance of equal educational opportunity for all (Reyes 2010,12). Thus, when compared to the mixed ability grouping at school $\mathrm{C}$, the screening at school $\mathrm{A}$ and the allocation of form one classes based on grade 
seven results at school $\mathrm{B}$ constituted instances of discrimination.

At lower sixth form level, labelling learners in terms of screening processes which were in operation at schools A and B was more or less similar to those in operation for form three learners of the same schools. Learners were strictly screened by schools at lower sixth level, using O-level final examination symbols: First As, then Bs and lastly Cs. However, differences appeared in that school $\mathrm{C}$ prospective lower sixth form learners' subject choices were considered by the school and they only required basic passes (i.e. Cs) at O-level. A male school $\mathrm{C}$ lower sixth sciences teacher revealed if someone is really interested in say, science, he or she will end up taking that combination, despite the lower passes.

Thus, labelling learners through screening in order to determine which schools they should attend proved to be a challenge, being mainly based on schools selecting learners with the best results first (as happened at government schools A and B). This is an indictment on the Zimbabwean education system.

\section{Streaming as a form of labelling learners}

Streaming sees learners being placed in different classes based on their overall academic ability (Harrison 2013). The streaming at the schools under study here, was done at form three and lower sixth form levels.

Schools A and B's learners were streamed into form one classes based on their grade seven examination results; into form three classes based on their form two results; and into lower sixth classes based on their O-level examination results. The top class was reserved for learners taking science subjects, followed by the commercials, and lastly those taking arts subjects. However, at school $\mathrm{C}$ there was a random grouping of learners in forms one and two, while in forms three and lower sixth learners were grouped into classes (of arts, commercials and sciences) based not only on performance, but also on their interests, feelings and strengths.

Labelling learners through streaming, as practised at schools A and B, presented certain challenges. A male school B form three commercials learner, for instance, said if you group people of higher potential they will be learning on their own and they will make positive results on their own whilst those of lower potential who will be on their own will be negatively affected since they will not have anyone to emulate.

According to Bandura's (1971) Social Learning Theory, human beings also learn by observing and emulating others. As a female school B form three arts teacher stated teachers don't really put much effort in the "worst" classes, but the better classes. Labelling also tends to affect the learners behaviour, their label states that they are the worst class and consequently the learners behave as such. Hence, through labelling a statement is made to the learners that they belong to a particular grouping of people, as reflected in their label/name. Through naming, ability and recognition can be socially constructed (Hay \& Macdonald $2010,1)$. Thus, learners might behave in accordance with the label they are given, therefore making this a self-fulfilling prophecy.

At school C, however, the learners identified with the labelling. For instance, a female lower sixth arts learner stated I am confident about my decision. I am going to show them that if they can be medical doctors I can also be a doctor in law, political science, and so on using the arts subjects I chose. Streaming therefore seemed to work when learners' differences were 
recognised and their choices acknowledged in the selection criteria. Therefore, learners' different talents (arts, commercials, sciences, and so on) need not become a bone of contention or a point of departure, but should rather represent a point of convergence, enabling greater complementarity in a bid to serve humanity.

\section{Conclusions}

The analysis and discussion of the data revealed that the labelling of Zimbabwean secondary school learners (based on school type, subjects learnt and performance) is a barrier to the learning of many (especially poor-performing) learners. The process of labelling - in terms of choosing which schools learners should attend, which classes they must be placed in, and which subjects they need to take - is mainly determined by agents from the home (parents, guardians or siblings) and school (school heads and teachers), rather than the learners themselves. Thus, in this respect labelling does not adequately serve the needs of the majority of learners.

There are various forms of labelling in operation in Zimbabwean secondary schools. School types include former group A government schools/secondary 1 (S1), former group B government school/secondary 2 (S2) schools and private schools. Due to the schools' diverse characteristics, each school's learners have their own label. Thanks to the process of screening, learners in government schools are more affected than those in private schools, being enrolled on having achieved a certain higher pass grade, especially in forms three and lower sixth. In the private school a first-come-first-served policy is adhered to, provided that a learner obtained the national minimum pass and can afford the school fees. Streaming affects learners at government schools, in that they are grouped into classes in forms one, three and lower sixth based on their overall performance. By basing groupings on subject combinations, learners in forms three and lower sixth - especially at government schools - are allocated subjects whereby those with the highest passes take science-related subjects, followed by those taking commercials, and learners with the fewest passes being pressured to take artsrelated subjects.

Some means of labelling learners, for instance through streaming, as Matavire et al. (2012) found, date back to Zimbabwe's colonial era. Thus, the spill-over effects of labelling have affected learning in Zimbabwe for over a century. The need to address this issue is of paramount importance, and in this regard the authors offer a number of recommendations.

\section{Recommendations}

These recommendations are based on the findings and conclusions of the doctoral study of the first author. As the pragmatic approach advocates, these recommendations should represent an attempt at determining and implementing what works, in terms of addressing the challenges emanating from the labelling of learners.

Learners need to be responsible for the process of their own labelling. The home (parents, guardians, older/caretaker siblings) should thus allow them to choose which school to attend (within their means) and not force them to enrol at a particular school. Furthermore, schools should guide and advise (not force) learners in choosing their classes and subjects, by letting them make informed choices in line with their abilities, interests and feelings, especially in lower sixth form (something that does not happen in government schools in Zimbabwe).

The random placement of learners in classes according to their subject choices in forms one 
and two enhances learners' equal opportunities at learning, and exposes their inclination to learn (which will help make it more fair when grouping them at a higher level). The random grouping of learners in forms one to four, and consideration of their choice of subjects at lower sixth level, could ameliorate the negative effect of labelling through naming. Schools have to educate learners during assemblies and at prize-giving ceremonies on the fact that different subject combinations are valid in their own right, and that they are vital in any society as they complement one another.

There is also a need to competitively improve the management, teaching and learning in schools, for example, through apprenticing less successful schools to those that are more successful. This will help to eliminate labelling by type or rank. A Zimbabwe education policy instrument which specifically directs enrolment at all schools in forms one, three and lower sixth, of learners who qualify, and based on a first-come-first-served basis, would serve learners better - it would also grant them an equal opportunity to education, in line with the International Human Rights Charter.

The research has found that the practice of labelling secondary school learners based on performance, subject combinations and school type, fails to meet the needs of many schoolgoing children, especially slow learners (although it benefits fast learners to some extent). In the main, labelling was found to be a barrier to learning, and the practice was pervasive throughout the country. The findings indicate a need to offer recommendations in dealing with, and eventually eliminating, such labelling. A proposed policy framework which serves as a guideline (in addition to other guidelines) for addressing the labelling of secondary school learners in Zimbabwe was included in author Rwodzi's thesis (not reflected here due to page limitations) as an original contribution to this significant field of research.

\section{Acknowledgement}

Student, M Rwodzi passed away before his DEd certificate could be conferred upon him at the graduation ceremony on the 3 October 2016 at the South African university where he completed his doctoral thesis. His supervisors completed this article on his behalf.

\section{References}

Adodo, S., \& Agbayewa, J.O. (2011). Effects of homogenous and heterogenous ability grouping class teaching on student's interest, attitude and achievement in Integrated Science. International Journal of Psychology and Counselling 3 (3): 48-54.

Agbenyega, J. (2012). The power of labelling discourse in the construction of disability in Ghana. Retrieved 15 January 2013 from aare.edu.au/03pap/agbo 3245.pdf

Arends, R. (2009). Learning to teach (8th ed.). New York: McGraw Hill.

Bandura, A. (1971). Social Learning Theory. New York: General Learning Press.

Bosire, J., Mondoh, H., \& Barmao, A. (2008). Effect of streaming by gender on student achievement in mathematics in secondary schools in Kenya. South African Journal of Education 28: 595-607.

Bronfenbrenner, U. (1994). Ecological models of human development. International Encyclopedia of Education, 3.

Charmaz, K. (2006). Constructing grounded theory: A practical guide through qualitative analysis. London: Sage.

Chisaka, B.C., \& Vakalisa, N.G.G.. (2003). Some effects of ability grouping in Harare secondary schools: A case study. South African Journal of Education 23 (3): 176180. 
Creswell, J.W. (2007). Qualitative inquiry and research design. London: Sage.

Ferrare, J. (2013). The duality of courses and students: A field-theoretical analysis of secondary school course-taking. Sociology of Education 86 (2): 139-157.

Freire, P. (2005). Pedagogy of the oppressed (30 ${ }^{\text {th }}$ anniversary ed.). New York: Continuum.

Gibson, B., \& Brown, A. (2009). Working with qualitative data. London: Sage.

Giddens, A. (2009). Sociology ( $4^{\text {th }}$ ed.). Cambridge: Polity Press.

Hallam, S., \& Parsons, S. (2013). Prevalence of streaming in UK primary schools: Evidence from the Millennium Cohort Study. British Educational Research Journal 39 (3): 514544.

Haralambos, M., Holborn, M., Chapman, S., \& Moore, S. (2013). Sociology: Themes and perspectives $\left(8^{\text {th }}\right.$ ed.). London: Harper Collins.

Harrison, A. (2013). Summer-born hit by school streaming. Retrieved 8 March 2013 from http://www.bbc.co.uk/news/education-21699054

Hay, P.J., \& Macdonald, D. (2010). Evidence for the social construction of ability in physical education. Sport, Education and Society 15 (1): 1-18.

Howitt, D. (2010). Introduction to qualitative methods in psychology. Harlow, England: Pearson Education Ltd.

Lu, L. (2012). The market phenomenon in Taiwanese junior high level education: Behind the battles between streaming and mixed-ability grouping. Comparative Education 48 (3): 367-383.

Mahmud, Z. (2009). A discriminant analysis of perceived attitudes towards statistics and profiles identification of statistics learners. Retrieved 5 October 2015 from http://www.Wseas.us/e

Matavire, M., Mukavhi, L., \& Sana, A.F. (2012). Homogeneous grouping and mixed ability: A comparative approach on two rural secondary schools in Muzarabani District, Zimbabwe. International Journal of Humanities and Social Science 2 (4): 279-286.

Mufanechiya, T. and A. Mufanechiya. (2011). Motivating Zimbabwean secondary school students to learn: A challenge. Journal of African Studies and Development 3 (5): 96104.

Oliver, P.( 2010). Understanding the research process. London: Sage.

Osterholm, K., Nash, W.R., \& Kristons, W.A.(2007). Effects of labelling students learning disabled. Focus on Colleges, Universities and Schools 1 (1).

Patterson, C.J. (2008). Child development. Boston: McGraw-Hill.

Petty, G. (2009). Teaching today: A practical guide ( $4^{\text {th }}$ ed.). Cheltenham, United Kingdom: Nelson Thornes.

Republic of Zimbabwe. (1996). Zimbabwe Education Act (Chapter 25:04, Revised Edition). Harare: Government Printer.

Reyes, X.A. (2010). Educational equity and access as universal human rights: Effects on teacher education in the United States of America. International Journal of Educational Sciences, 2 (1): 1-20.

Riddell, A.R., \& Nyagura, L.M. (1991). What causes differences in achievement in Zimbabwe's secondary schools? Retrieved 10 January 2013 from www.unesco.org/education/.../liste complete.html-France

Ritchie, J. (2008). The applications of qualitative methods to social research. In J. Ritchie \& J. Lewis (Eds.), Qualitative research practice: A guide for social science students and researchers. London: Sage.

Rwodzi, M. (2006). Similarities and differences in attitudes towards mathematics among Form 3 pupils in Gweru urban schools. Zimbabwe Journal of Education Research 18 (3): 420-439. 
Sanders, D. (2013). A system divided: Gifted, talented and separated. The New York Times January 13.

Segedin, L. (2012). Listening to the student voice: Understanding the school-related factors that limit student success. McGill Journal of Education 47 (1): 93-107.

The free dictionary (2012). The free dictionary. Retrieved 15 December 2012 from http://www.thefreedictionary.com/

Unesco (2008) Policy briefs. Retrieved 15 January 2013 from www.ibe.org/en/themes/...education/policy-briefs.html

Woolfolk, A. (2014). Educational psychology (12 ${ }^{\text {th }}$ ed.). New York: Pearson. 